\title{
Public perception of climate change and its impact on health and environment in rural southwestern Nigeria
}

This article was published in the following Dove Press journal:

Research and Reports in Tropical Medicine

10 February 2014

Number of times this article has been viewed

\section{Esther O Asekun- \\ Olarinmoye ${ }^{\prime}$ \\ James $O$ Bamidele ${ }^{2}$ \\ Olusola O Odu ${ }^{2}$ \\ Adenike I Olugbenga-Bello ${ }^{3}$ \\ Olugbenga L Abodurin ${ }^{3}$ \\ Wasiu O Adebimpe' \\ Edward A Oladele ${ }^{4}$ \\ Adeleye A Adeomi ${ }^{3}$ \\ Oluwatosin A Adeoye ${ }^{3}$ \\ Ebenezer O Ojofeitimi ${ }^{3}$}

'Department of Community Medicine, College of Health Sciences, Osun State University, Osogbo, Nigeria; ${ }^{2}$ Department of Community Medicine, College of Health Sciences, Ekiti State University, Ado Ekiti, Nigeria; ${ }^{3}$ Department of Community Medicine, College of Health Sciences, Faculty of Clinical Science, Ladoke Akintola University of Technology, Ogbomosho, Nigeria; ${ }^{4}$ SIDHAS Project, Family Health International, Abuja, Nigeria
Correspondence: Esther O AsekunOlarinmoye

Department of Community Medicine, College of Health Sciences, Osun State University, PMB 4494, Osogbo, Nigeria Email esther.asekun-olarinmoye@ uniosun.edu.ng
Background: Climate change $(\mathrm{CC})$ has received extensive media attention recently, and it is currently on the international public health agenda. A study of knowledge and attitudes to climate change, most especially from rural Nigerian communities, is important for developing adaptation strategies. This is a study of public perceptions of CC and its impact on health and environment in rural southwestern Nigeria.

Methods: This was a community-based descriptive cross-sectional study of 1,019 rural respondents using a multistage sampling method. The research instrument used was a pretested, structured, interviewer-administered questionnaire. Data were analyzed using SPSS software. $\chi^{2}$, Cramér's $V$, and Kendall's $\tau$-c statistics were employed in addition to fitting the data to a logistic regression model to explore associations found significant on bivariate analysis.

Results: Mean age of respondents was 36.9 ( \pm 12.4$)$ years. About $911(89.4 \%)$ of respondents opined that there has been a change in climate in the last 10 years. Supernatural reasons were prominent among respondent-reported causes of CC. Identified risky behavior contributing to CC included smoking (10.7\%), bush burning (33.4\%), and tree felling (41.0\%). Poor knowledge of causes but good knowledge of effects of $\mathrm{CC}$ were found in this study. About two-thirds of respondents had a positive attitude to causes of $\mathrm{CC}$, while half had a positive attitude to the effects of CC. A significant association was found between educational status $(P<0.001$, Kendall's $\tau$-c $=-0.042)$, occupational status $(P<0.01$, Kendall's $\tau$-c $=0.088)$, and attitude to causes of CC. Further analysis using logistic regression showed that occupational status was significantly associated with likelihood of having a positive attitude, but educational status and marital status were not.

Conclusion: Rural areas of Nigeria are vulnerable to the adverse effects of CC. Respondents' poor knowledge but positive attitude to $\mathrm{CC}$ calls for dissemination of adequate information on $\mathrm{CC}$ in sustained health-promotion programs.

Keywords: climate change, global warming, public perception, rural child health, environmental effect

\section{Introduction}

The World Health Organization (WHO) chose "protecting health from climate change" as the theme for World Health Day a few years ago. This theme was selected in recognition of the fact that climate change (CC) is posing ever-growing threats to global public health security and that "wherever you live, climate change threatens your health." The impacts of CC are apparent historically, currently important, and will continue to be important in both the short and long term.

The most recent report of the Intergovernmental Panel on Climate Change estimates current global warming to be almost $0.8^{\circ} \mathrm{C}$ above preindustrial levels, and 
projects a further rise in the coming decades. This report also reconfirms that it is human emission of greenhouse gases that has been mostly responsible for global warming over the past 50 years. Even if emissions are greatly curtailed, the existing accumulation of emissions in the earth's atmosphere has committed it to some warming over the coming century. The impacts of current global warming are now observable in physical systems, such as the rise of sea levels, glacial retreat, significant reductions in the extent and thickness of Arctic sea ice, and alterations in rainfall patterns, and in biological systems, such as earlier spring activities of numerous plant and animal species. ${ }^{1}$

Research on the health effects of CC has focused largely on direct physical health impacts, principally death and injury from extreme-weather events, impacts of increased temperatures and heat waves, spread of vector-borne disease, air quality and respiratory illness, and changes in food and water quality and availability., ${ }^{2,3}$ The WHO estimates that CC already accounts for more than 60,000 deaths globally from climate-related natural disasters every year, ${ }^{4}$ along with at least another 100,000 deaths from malaria, malnutrition, and child diarrhea. ${ }^{5}$

It is anticipated that there will be changes in airborne pollutants, leading to increased respiratory problems. The incidence of some infectious diseases, such as gastroenteritis, is predicted to rise, and there will be changes in the distribution and intensity of mosquito-transmitted diseases, such as malaria, yellow fever, and dengue fever. Research has suggested that the risks of diarrheal disease may be augmented by the increased temperatures that result from CC. One study showed that for every degree of increase in temperature, the rate of hospitalization of children with diarrhea increased by $8 \%{ }^{6}$ It has also been predicted that gastrointestinal infections, which are already common in our community, are likely to increase with higher temperatures. ${ }^{7,8}$ The more vulnerable members of our community will be most affected by climate-related illnesses. These include the elderly, who cope less well with changes in temperature, and young children, whose developing lungs are susceptible to ambient air pollution.

The potential child-health impacts of severe weather include drowning, gastrointestinal disease, malnutrition, and psychological trauma. ${ }^{7}$ Health indicators in children, such as infant mortality rate and under-five mortality rate, are already unacceptably high in Nigeria. More importantly, the prevalence of childhood malnutrition in rural areas has been reported to be much higher than in urban settings in Nigeria. ${ }^{9}$ The health impacts of CC on children, especially rural children, who are most often marginalized, will be an additional burden. ${ }^{6}$

However, key studies into the ways in which laypeople perceive $\mathrm{CC}$ have found that in general people exhibit misconceptions about the causes and consequences of CC. ${ }^{10,11}$ In addition, it was found that these misunderstandings had the propensity to cause fear about the consequences of CC. ${ }^{12}$ However, for people to be willing to make sacrifices or direct wealth and effort to respond to $\mathrm{CC}$ will require a considerable recognition of the importance of environmental change management for their own lives, and associated guidance from government. Awareness and knowledge of issues are necessary precursors for people to take appropriate action. This paper provides important information on community perspectives of $\mathrm{CC}$ and its impact on rural health in this environment with the aim of providing policy makers insights into this important public health issue.

\section{Materials and methods Description of study area}

Osun State is one of the thirty-six states of Nigeria. It is divided into 30 local government areas (LGAs) comprising both rural and urban communities. The vegetation is of a tropical rain-forest type, which could be explained by the heavy rainfall in the area. The climate of Osun State is tropical, with the rainy season beginning in March and ending in September or early October. The harmattan, or dry season, commences at the end of the rainy season and ends in March. According to the 2006 population census result, the population of Osun State was about 3.5 million. The percentage of males is $49.4 \%$ for males, and of females $50.6 \%$.

\section{Design}

This was a community-based descriptive cross-sectional study. Sample-size estimation was determined by Fisher's formula for populations $>10,000$. The desired sample size was estimated at $384 ; 20 \%$ of the estimated sample size was added to make up for possible nonresponse, which brought the sample size to 406.

Multistage sampling was used to select respondents for the study. In stage one, two LGAs (Olorunda and Ede South LGA) were selected by a simple random sampling technique utilizing the ballot method from the existing 30 LGAs in Osun State. In stage two, two rural villages were chosen by a simple random sampling technique from the sampling frame of all villages in the each of the selected LGAs. In stage three, for each village chosen, streets were selected using a systematic sampling method. In stage four, for each street selected, 
houses were selected using a systematic random sampling method. In stage five, for each house, all consenting adults (18 years and above) were interviewed till the total sample size was obtained.

\section{Study instrument}

The main instrument used for the study was a pretested structured interviewer-administered questionnaire. Questionnaire administration was conducted by trained research assistants who could also speak the local language. A vernacular version of the questionnaire was prepared for the uneducated respondents; this was back-translated into English to reduce interobserver variation in interpretation during the interview. The questionnaire sought information about the sociodemographic characteristics of the respondents, and their knowledge, perceptions, and attitudes about the causes and effects of $\mathrm{CC}$ and its impact on rural child health.

\section{Ethical considerations}

After explaining the rationale for the study to the respondents, written informed consent was obtained from each respondent. The few respondents who could not read or write gave their consent through thumbprints and verbal consent. Approval to conduct the study was obtained from the Research Ethics Committee of Ladoke Akintola University of Technology Teaching Hospital, Osogbo. Permission was also obtained from the heads of communities selected to take part in the study.

\section{Data analysis}

The data collected were edited manually and then entered into a computer. SPSS version 16 (IBM, Armonk, NY, USA) was used for analysis of data. Sociodemographic variables and respondent responses were summarized and presented using frequency tables.

Attitudes about the causes and effects of $\mathrm{CC}$ were measured on a 5-point Likert-scale. The different components on the matrix were aggregated into a composite attitudinal score, which was then regrouped into a positive or negative attitude by virtue of scores above or below the mean composite score. An indifferent response was scored zero, correctly scoring correct answers as either agree/disagree or strongly agree/strongly disagree were scored as +1 , while wrongly scoring a correct answer attracted a score of -1 . The mean composite score of these responses were calculated. Scores above the mean were positive, while scores below the mean were regarded as negative. This scoring was done for all questions related to attitude about either the cause or effect of CC. The same was done for knowledge of either the cause or effect of CC.

Evidence of association between sociodemographic variables and attitudes was explored by cross-tabulation and measured using the $\chi^{2}$ statistic. When an association was found, the strength of this association was examined using Cramér's $V$-statistic for nominal variables or Kendall's $\tau$-c for ordinal variables. The logistic regression model was used to further explore associations that were found to be significant on bivariate analysis.

\section{Study limitation}

The fact that this study was carried out in a rural adult population underscores the fact that results generated can be generalized only to rural populations. Rural-urban migration and adoption of Western lifestyle by respondents could also affect respondent's awareness and attitude to climate change. Sex bias is also a possibility, since farming in the study area is almost exclusively an occupation for men, in contrast to the situation in the eastern part of Nigeria, where females are actively involved in the farming business.

\section{Results}

The 1,019 respondents included in the study comprised 392 males (38.5\%) and 627 females (61.5\%). The mean age of the respondents was 36.9 years, with a standard deviation of 12.4 years. The majority was in early adulthood (57.5\%), Muslim (65.6\%), and currently married (83.4\%), as shown in Table 1. The study was located in southwestern Nigeria, and thus had respondents who were mainly Yoruba (97.4\%). Respondents largely had low social class indices: only $12.9 \%$ of respondents had postsecondary education or higher, only $5.6 \%$ were professionals, and only $15.3 \%$ earned a monthly income above $10,000.00$ (Table 1).

$\mathrm{CC}$ meant different things to respondents. The majority $(54.0 \%)$ felt that $\mathrm{CC}$ was a change in the periodicity/pattern of rainfall. Some $(37.0 \%)$ felt that $\mathrm{CC}$ was reduced rainfall or drought, while some (28.6\%) thought it was prolonged dry season. CC was deemed to be the work of God by a fifth of respondents and a natural occurrence by $7.0 \%$ of respondents. As many as $12.8 \%$ of respondents had no idea what the term "climate change" meant, with $10.6 \%$ claiming not to have noticed any change in the climate in the past 10 years preceding the study (Table 2 ).

When respondents were asked to state reasons for $\mathrm{CC}$, responses varied from CC being God's work (37.3\%) to it arising from the sins of man (7.2\%). Respondents who felt that $\mathrm{CC}$ was due to civilization/modernization were $2.4 \%$. 
Table I Sociodemographic characteristics of respondents

\begin{tabular}{|c|c|}
\hline Variables $(n=1,019)$ & $\begin{array}{l}\text { Frequency } \\
\text { (percentage) }\end{array}$ \\
\hline \multicolumn{2}{|l|}{ Age } \\
\hline Young persons $(<25$ years) & $121(11.9)$ \\
\hline Early adulthood ( $25-40$ years) & $586(57.5)$ \\
\hline Middle age (4I-60 years) & $271(26.6)$ \\
\hline Old age ( $>60$ years) & $4 \mid(4.0)$ \\
\hline Mean age, years & 36.9 \\
\hline Standard deviation & 12.4 \\
\hline \multicolumn{2}{|l|}{ Sex } \\
\hline Male & $392(38.5)$ \\
\hline Female & $627(6 \mid .5)$ \\
\hline \multicolumn{2}{|l|}{ Religion } \\
\hline Christianity & $333(32.7)$ \\
\hline Islam & $668(65.6)$ \\
\hline Traditional & $18(1.8)$ \\
\hline \multicolumn{2}{|l|}{ Marital status } \\
\hline Single (never married) & $102(10.0)$ \\
\hline Currently married & $850(83.4)$ \\
\hline Previously married & $67(6.6)$ \\
\hline \multicolumn{2}{|l|}{ Ethnicity } \\
\hline Yoruba & $992(97.4)$ \\
\hline Others & $27(2.7)$ \\
\hline \multicolumn{2}{|l|}{ Educational status } \\
\hline No formal education & $200(19.6)$ \\
\hline Primary education & $326(32.0)$ \\
\hline Secondary education & $362(35.5)$ \\
\hline Postsecondary & $67(6.6)$ \\
\hline Tertiary education & $64(6.3)$ \\
\hline \multicolumn{2}{|l|}{ Occupational status } \\
\hline Unemployed & $110(10.8)$ \\
\hline Unskilled jobs & $583(57.2)$ \\
\hline Skilled jobs & $269(26.4)$ \\
\hline Professionals & $57(5.6)$ \\
\hline \multicolumn{2}{|l|}{ Average monthly income } \\
\hline$<\# I, 500$ & $163(16.0)$ \\
\hline$\# 1,600-\# 2,500$ & $168(16.5)$ \\
\hline$\# 2,600-\# 5,000$ & $316(31.0)$ \\
\hline$\# 5,100-\$ 10,000$ & $216(21.2)$ \\
\hline$>\$ 10,000$ & $156(15.3)$ \\
\hline
\end{tabular}

Almost a fifth of respondents did not know the reasons for CC (Table 2).

The various effects of CC were explored (Table 3 ). Most respondents stated that $\mathrm{CC}$ will have an effect on food production. While $80.5 \%$ stated that $\mathrm{CC}$ will lead to reduced food production, $7.7 \%$ actually stated that it will lead to increased food production. About two-thirds of respondents stated that CC will lead to drying up of wells, while some $(10.6 \%)$ stated that it will lead to increased water supply. This increased water supply was different from flooding, which was mentioned by $4.1 \%$ of respondents. Respondents were however less committed to stating how they felt that $\mathrm{CC}$ will affect farmland. The highest proportion of respondents who
Table 2 Knowledge of respondents about climate change

\begin{tabular}{ll}
\hline Variables ( $\mathbf{n}=\mathbf{I}, \mathbf{0}$ I 9) & $\begin{array}{l}\text { Frequency } \\
\text { (percentage) }\end{array}$ \\
\hline The meaning of climate change & $223(21.9)$ \\
God's work & $377(37.0)$ \\
Reduced rainfall/drought & $550(54.0)$ \\
Change in the periodicity/pattern of rainfall & $291(28.6)$ \\
Prolonged dry season & $71(7.0)$ \\
Natural occurrence & $30(2.9)$ \\
Others & $130(12.8)$ \\
I don't know & \\
Has there been any change in climate in the last I0 years? & $911(89.4)$ \\
Yes & $108(10.6)$ \\
No & \\
Causes or reasons for climate change & $380(37.3)$ \\
God's work & $94(9.2)$ \\
Change in rainfall & $88(8.6)$ \\
Prolonged dry season and excessive heat & $56(5.5)$ \\
Excessive sunlight & $73(7.2)$ \\
Men's sins & $8(0.8)$ \\
Increased population & $40(3.9)$ \\
Change in weather & $117(11.5)$ \\
Men's activities & $24(2.4)$ \\
Civilization/modernization & $24(2.4)$ \\
It is a natural occurrence & $60(5.9)$ \\
Others & $189(18.5)$ \\
I don't know &
\end{tabular}

stated that CC will affect farmland was $18.1 \%$. These $18.1 \%$ stated that $\mathrm{CC}$ will lead to hard and infertile soil.

In addition to the effects on the elements, the knowledge of respondents about the effects on humans was also captured. Respondents knew that CC could lead to ill health (46.5\%), increased stress and suffering (25.1\%), hunger (12.5\%), and decreased income (14.9\%), amongst other responses. Only $2.2 \%$ of respondents stated that scarcity of water for domestic use was a distinct effect that affected females differently from males. Effects distinct to children stated by respondents included delayed/poor growth $(8.0 \%)$ and death (1.7\%) (Table 3).

Recognition of the pivotal role of government in controlling CC was evident in the responses, as $13.2 \%$ of respondents listed government intervention as the necessary measure. More than four of ten respondents, however, felt that praying to God was the appropriate measure to take. Some respondents (8.1\%) had adopted a "nothing can be done" belief, while some $(1.7 \%)$ would urge humans to stop sinning as a means of stopping CC (Table 4). In stating the measures that could be taken to protect the health of children, four of ten respondents stated that provision of good health services was the key. Only two of ten respondents stated that praying to God was a remedy in this regard. 
Table 3 Knowledge of respondents about the effects of climate change on human health and the environment

\begin{tabular}{ll}
\hline Variables (n=I,0I9) & $\begin{array}{l}\text { Frequency } \\
\text { (percentage) }\end{array}$ \\
\hline Effect on men and women & \\
Sickness/disease & $474(46.5)$ \\
Increased stress/suffering & $256(25.1)$ \\
Decreased productivity & $89(8.7)$ \\
Hunger & $127(12.5)$ \\
Excessive heat & $94(9.2)$ \\
Increased comfort & $58(5.7)$ \\
Death & $29(2.8)$ \\
Dryness of the skin & $25(2.5)$ \\
Depression & $17(1.7)$ \\
Rural-urban migration & $5(0.5)$ \\
Decreased income & $152(14.9)$ \\
Scarcity of water for domestic use & $22(2.2)$ \\
Effect on children's health & \\
Sickness/disease & $715(70.2)$ \\
Hunger and malnutrition & $69(6.8)$ \\
Excessive heat & $75(7.4)$ \\
Improved health & $19(1.9)$ \\
Delayed or poor growth & $82(8.0)$ \\
Death & $17(1.7)$ \\
Effect on food production & \\
Rise in cost of food crops & \\
Increased food production & $401(39.4)$ \\
Reduced food production & $78(7.7)$ \\
I don't know & $820(80.5)$ \\
Effect on water supply and water sources & $21(2.1)$ \\
Water contamination/pollution & $182(136(13.3)$ \\
Drying up of wells and rivers & $63(6.2)$ \\
Increased water supply & $124(12.2)$ \\
Reduced water supply & $184(18.1)$ \\
Flooding &
\end{tabular}

About two-thirds of respondents $(65.3 \%)$ had positive attitudes to the causes of $\mathrm{CC}$, while $55.1 \%$ had positive attitudes to the effects of CC (Figure 1). While expressing various dispositions, respondents were themselves engaged in various practices that contribute to $\mathrm{CC}$. These included smoking (10.7\%), bush burning (33.4\%), tree felling (41.0\%), and of those who felled trees, $85.2 \%$ never planted a replacement (Table 4).

Cross-tabulation was done to examine the association between sociodemographic variables and the attitude of respondents to causes and effects of CC (Table 5). Marital status was significantly associated with attitude to causes of $\mathrm{CC}(P=0.009)$. This association was however weak (Cramér's $V=0.097$ ). A significant $(P<0.001)$ but weak (Kendall's $\tau$-c $=-0.042$ ) association
Table 4 Risky practices and knowledge about control of climate change

\begin{tabular}{|c|c|}
\hline Variables $(n=I, 019)$ & $\begin{array}{l}\text { Frequency } \\
\text { (percentage) }\end{array}$ \\
\hline \multicolumn{2}{|l|}{ Smoking } \\
\hline Yes & $109(10.7)$ \\
\hline No & $886(86.9)$ \\
\hline \multicolumn{2}{|l|}{ Ever engaged in bush burning } \\
\hline Yes & $340(33.4)$ \\
\hline No & $672(65.9)$ \\
\hline \multicolumn{2}{|l|}{ Ever engaged in tree felling } \\
\hline Yes & $418(4 \mid .0)$ \\
\hline No & $574(56.3)$ \\
\hline \multicolumn{2}{|l|}{ Planted a tree to replace felled trees $(n=4 \mid 8)$} \\
\hline Yes & $62(14.8)$ \\
\hline No & $356(85.2)$ \\
\hline \multicolumn{2}{|l|}{ Measures to stop climate change } \\
\hline I don't know & $123(12.1)$ \\
\hline Nothing can be done & $83(8.1)$ \\
\hline Prayer to God & 477 (43.9) \\
\hline Good medical care & $71(7.1)$ \\
\hline Government intervention & $134(13.2)$ \\
\hline Stop sinning & $17(1.7)$ \\
\hline Personal hygiene & $21(2.1)$ \\
\hline Use of alternate sources of water for irrigation & $37(3.6)$ \\
\hline \multicolumn{2}{|c|}{ Measures to prevent adverse effect on the health of children } \\
\hline I don't know & $78(7.7)$ \\
\hline Nothing can be done & $44(4.3)$ \\
\hline Prayer to God & $209(20.5)$ \\
\hline Immunization & $230(22.6)$ \\
\hline Provision of good health services & $416(40.8)$ \\
\hline Government intervention & $23(2.3)$ \\
\hline Provision of potable water & $48(4.7)$ \\
\hline Good nutrition & $163(16.0)$ \\
\hline
\end{tabular}

was also found between educational status and attitude to causes of CC. Occupational status was also significantly associated with attitudes to causes of $\mathrm{CC}(P=0.01)$. This association was also weak, with a Kendall's $\tau$-c of 0.088 . As educational status could potentially confound the association found between occupational status and attitudes to CC, these three significant factors were further explored.

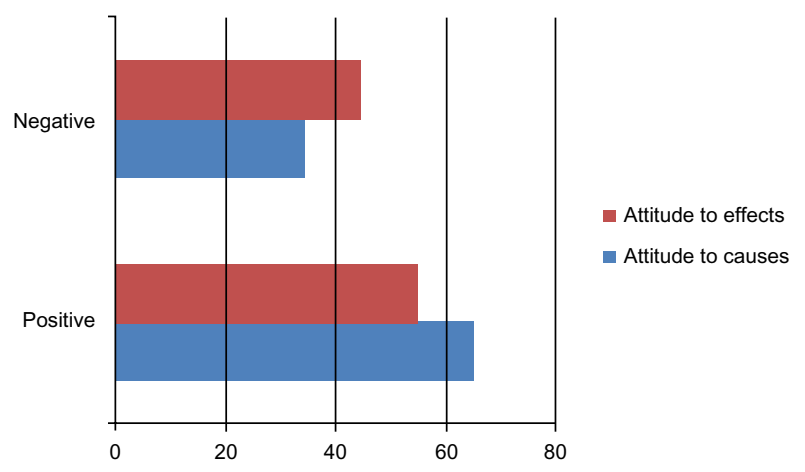

Figure I Respondents' attitudes to causes and effects of climate change $(n=|, 0| 9)$. 
Table 5 Association between sociodemographic variables and attitudes to causes of climate change

\begin{tabular}{|c|c|c|c|c|}
\hline & \multicolumn{3}{|c|}{ Attitude to causes of climate change } & \multirow[t]{2}{*}{ Statistics } \\
\hline & Negative & Positive & Total & \\
\hline \multicolumn{5}{|l|}{ Age-group } \\
\hline Young persons ( $<25$ years) & $37(30.6)$ & $84(69.4)$ & $|2|(100.0)$ & $\chi^{2}=5.702$ \\
\hline Early adulthood ( $25-40$ years) & $221(37.7)$ & $365(62.3)$ & $586(100.0)$ & $d f=3$ \\
\hline Middle age (4I-60 years) & $85(31.4)$ & $186(68.6)$ & $271(100.0)$ & $P=0.127$ \\
\hline Old age ( $>60$ years) & II (26.8) & $30(73.2)$ & $4 \mathrm{I}(100.0)$ & \\
\hline Total & $354(34.7)$ & $665(65.3)$ & $1,019(100.0)$ & \\
\hline \multicolumn{5}{|l|}{ Sex } \\
\hline Male & $123(31.4)$ & $269(68.6)$ & $392(100.0)$ & $\chi^{2}=3.177$ \\
\hline Female & $231(36.8)$ & $396(63.2)$ & $627(100.0)$ & $d f=1$ \\
\hline Total & $354(34.7)$ & $665(65.3)$ & $1,019(100.0)$ & $P=0.075$ \\
\hline \multicolumn{5}{|l|}{ Marital status } \\
\hline Never married/single & $30(29.4)$ & $72(70.6)$ & $102(100.0)$ & $\chi^{2}=9.510$ \\
\hline Currently married & $311(36.6)$ & $539(63.4)$ & $850(100.0)$ & $d f=2$ \\
\hline Previously married & $13(19.4)$ & $54(80.6)$ & $67(100.0)$ & $P=0.009$ \\
\hline Total & $354(34.7)$ & $665(65.3)$ & $1,019(100.0)$ & Cramér's $V=0.097$ \\
\hline \multicolumn{5}{|l|}{ Religion } \\
\hline Christianity & $114(34.2)$ & $219(65.8)$ & $333(100.0)$ & $\chi^{2}=0.785$ \\
\hline Islam & $232(34.7)$ & $436(65.3)$ & $668(100.0)$ & $d f=2$ \\
\hline Traditional & $8(44.4)$ & $10(55.6)$ & $18(100.0)$ & $P=0.675$ \\
\hline Total & $354(34.7)$ & $665(65.3)$ & $1,019(100.0)$ & \\
\hline \multicolumn{5}{|l|}{ Educational status } \\
\hline No formal education & $56(28.0)$ & I 44 (72.0) & $200(100.0)$ & $\chi^{2}=25.012$ \\
\hline Primary education & I $47(45.1)$ & $179(54.9)$ & $326(100.0)$ & $d f=4$ \\
\hline Secondary & $113(3 \mid .2)$ & $249(68.8)$ & $362(100.0)$ & $P<0.001$ \\
\hline Postsecondary & $23(34.3)$ & $44(65.7)$ & $67(100.0)$ & Kendall's $\tau$-c $=0.042$ \\
\hline Tertiary & $15(23.4)$ & $49(76.6)$ & $64(100.0)$ & $P=0.185$ \\
\hline Total & $354(34.7)$ & $665(65.3)$ & $1,019(100.0)$ & \\
\hline \multicolumn{5}{|l|}{ Occupational status } \\
\hline Unemployed & $40(36.4)$ & $70(63.6)$ & $110(100.0)$ & $\chi^{2}=11.431$ \\
\hline Unskilled labor & $223(38.3)$ & $360(61.7)$ & $583(100.0)$ & $d f=3$ \\
\hline Skilled labor & $79(29.4)$ & $190(70.6)$ & $269(100.0)$ & $P=0.010$ \\
\hline Professional & $12(21.1)$ & 45 (78.9) & $57(100.0)$ & Kendall's $\tau$-c $=0.088$ \\
\hline Total & $354(34.7)$ & $665(65.3)$ & $1,019(100.0)$ & $P=0.003$ \\
\hline \multicolumn{5}{|l|}{ Average monthly income } \\
\hline$<\# \mid, 500$ & $61(37.4)$ & $102(62.6)$ & $163(100.0)$ & $\chi^{2}=2.177$ \\
\hline$\# 1,600-\# 2,500$ & $57(33.9)$ & III (66.I) & $168(100.0)$ & $d f=4$ \\
\hline$\# 2,600-\# 5,000$ & $112(35.4)$ & $204(64.6)$ & $316(100.0)$ & $P=0.703$ \\
\hline$\# 5,100-10,000$ & $77(35.6)$ & $139(64.4)$ & $216(100.0)$ & \\
\hline$>\$ 10,000$ & $47(30.1)$ & $109(69.9)$ & $156(100.0)$ & \\
\hline Total & $354(34.7)$ & $665(65.3)$ & $1,019(100.0)$ & \\
\hline \multicolumn{5}{|l|}{ House ownership } \\
\hline Rented & $175(33.7)$ & $344(66.3)$ & $519(100.0)$ & $\chi^{2}=0.487$ \\
\hline Owned & $179(35.8)$ & $321(64.2)$ & $500(100.0)$ & $d f=I$ \\
\hline Total & $354(34.7)$ & $665(65.3)$ & $1,019(100.0)$ & $P=0.485$ \\
\hline \multicolumn{5}{|l|}{ Ethnicity } \\
\hline Yoruba & $345(34.8)$ & $647(65.2)$ & $992(100.0)$ & $\chi^{2}=0.024$ \\
\hline Others & $9(33.3)$ & $18(66.7)$ & $27(100.0)$ & $d f=I$ \\
\hline Total & $354(34.7)$ & $665(65.3)$ & $1,019(100.0)$ & $P=0.876$ \\
\hline
\end{tabular}

Logistic regression was used to examine the likelihood of having a positive attitude to causes of $\mathrm{CC}$ given different educational, occupational, and marital status (Table 6). Occupational status was significantly associated with likelihood of having a positive attitude, but educational status and marital status were not (Table 6). From each stratum of occupational status to another, respondents were 1.3 times more likely to have a positive attitude about causes of $\mathrm{CC}$ than those in the lower occupational stratum. The influence of educational status on the relationship between occupational status and 
Table 6 Binary logistic regression to explore association between marital status, educational status, and occupational status

\begin{tabular}{lllllll}
\hline Variables & B & SE & Wald & df & Significance & Exp (B) \\
\hline $\begin{array}{l}\text { Marital } \\
\text { status }\end{array}$ & 0.159 & 0.176 & 0.814 & $\mathrm{I}$ & 0.367 & $\mathrm{I} .172$ \\
$\begin{array}{l}\text { Educational } \\
\text { status }\end{array}$ & 0.042 & 0.073 & 0.325 & $\mathrm{I}$ & 0.568 & $\mathrm{I} .043$ \\
$\begin{array}{l}\text { Occupation } \\
\text { status }\end{array}$ & 0.244 & 0.102 & 5.779 & $\mathrm{I}$ & 0.016 & $\mathrm{I} .277$ \\
$\begin{array}{l}\text { Constant } \\
\text { Const }\end{array}$ & -0.333 & 0.443 & 0.564 & $\mathrm{I}$ & 0.453 & 0.717 \\
\hline
\end{tabular}

Notes: $B$ is the estimated logit coefficient; $\operatorname{Exp}(B)$ is the "odds ratio" of the individual coefficient.

Abbreviations: SE, standard error; $d f$, degrees of freedom.

attitudes was further explored by stratified analysis (Table 7). A consistently significant relationship was not found for all the strata of educational status. Having no formal education and having at least secondary school education had moderately strong significant association with attitude to causes of CC.

\section{Discussion}

$\mathrm{CC}$ meant different things to respondents. These included the fact that $\mathrm{CC}$ was a change in the periodicity/pattern of rainfall (half), reduced rainfall (a third), drought (a third), and prolonged dry season (another third), while a tenth had no idea. This agreed with a study in which $\mathrm{CC}$ was defined by most as variation in global change and change in weather patterns. ${ }^{12}$ In another study, most respondents mentioned hurricanes, droughts, global warming, and flood events when asked about definitions of CC. ${ }^{12}$ In yet another study, most meant change in rainfall pattern, and few said it means change in temperature, while a little over a tenth had no idea. ${ }^{13}$

Most of our respondents said there had been a change in climate in the last 10 years. This supports other studies in which most also said that the climate had changed and that heat during the summers had increased, and rainfall had decreased compared to their previous experiences. ${ }^{12,14}$ In yet another study, ${ }^{15}$ rainfall and runoff was noticed by the majority to have reduced in the last 10 years, and growing seasons were changing for two-thirds of respondents. $\mathrm{CC}$ has received recent extensive media attention (eg, Kyoto Protocol), and is currently on the international public health agenda, continuously drawing the attention of all to its existence.

As regards causes or reasons for $\mathrm{CC}$, most of our respondents said it was due to a change in rainfall, God's work (a third), sins of man (less than a tenth), increased population (very few), and change in weather (two-fifths). In a similar study, causes mentioned by most respondents included deforestation and improper disposal of refuse (burning garbage). ${ }^{12}$ In yet another study, the majority said it was caused by the cutting down of trees, and half said it was due to greenhouse gases. ${ }^{13}$ In another similar study, half attributed it to greenhouse gases, holes in the ozone layer, burning of vegetation, and vehicular exhaust gases. ${ }^{16}$ The less scientific reasons given by respondents in our study could be due to low educational status, as only about a tenth had tertiary education, a low exposure by virtue of their unskilled and unprofessional occupational status. The fact that they are in rural areas could explain the thinking along the traditional African setting and belief in supernatural powers.

As regards the effects of $\mathrm{CC}$ on the environment, most respondents stated that $\mathrm{CC}$ will lead to reduced food production (most), reduced water supply (half), drying up of wells (about two-thirds), flooding (4.1\%), and adverse effect on farmlands (about a fifth). This supports another study with similar findings. ${ }^{13}$ In yet another supportive study, threequarters reported that water security could be an effect of CC..$^{15}$ As our respondents were farmers, evidence of a link between rainfall and $\mathrm{CC}$ would influence the interest of grain and dairy farmers about $\mathrm{CC}$.

As regards the effects of $\mathrm{CC}$ on humans, $\mathrm{CC}$ could lead to ill health (half), increased stress and suffering (a quarter), and hunger (an eighth). In a similar study that corroborates our findings, effects of $\mathrm{CC}$ mentioned were health, water resources, agriculture, biodiversity, and coastal degradation, in order of importance. In other studies, CC effects included heat-related illnesses, ${ }^{17}$ cold-related illnesses, wateravailability illnesses, and malnutrition. ${ }^{18}$ Effects on children as reported by our study include sickness, poor growth, and malnutrition. This corroborates another study, ${ }^{19}$ which was carried out among children that documented the deleterious effects of CC on their respiratory system.

Risky practices our respondents felt contributed to the occurrence of CC included smoking (a tenth), bush burning (a third), and tree felling (two-fifths). A related study also showed that risky behavior, such as improper waste disposal, deforestation, and increased energy use, was a contributory factor to the occurrence of CC. ${ }^{12}$

In addition, smoke coming from tobacco, traditional sniffing, which is a common practice in rural areas, and even bush burning are agents of atmospheric pollution. Smoke coming from tobacco or the native sniffs could lead to gaseous emissions that would bring about depletion of the ozone layer and contribute to greenhouse gases. Villagers often resort to this pattern of smoking as a relief measure for long periods of stress on the farm and daily trekking over long distances.

In this study, preventive measures were believed by respondents essentially to lie with government intervention 
Table 7 Association between sociodemographic variables and attitudes to effects of climate change

\begin{tabular}{|c|c|c|c|c|}
\hline & \multicolumn{3}{|c|}{ Attitude to effects of climate change } & \multirow[t]{2}{*}{ Statistics } \\
\hline & Negative & Positive & Total & \\
\hline \multicolumn{5}{|l|}{ Age-group } \\
\hline Young persons ( $<25$ years) & $59(48.8)$ & $62(5 \mid .2)$ & $|2|(\mid 00.0)$ & $\chi^{2}=1.131$ \\
\hline Early adulthood ( $25-40$ years) & $264(45.1)$ & $322(54.9)$ & $586(100.0)$ & $d f=3$ \\
\hline Middle age ( $4 I-60$ years) & I 18 (43.5) & $153(56.5)$ & $271(100.0)$ & $P=0.770$ \\
\hline Old age ( $>60$ years) & $17(4 \mid .5)$ & $24(58.5)$ & $41(100.0)$ & \\
\hline Total & $458(44.9)$ & $561(55.1)$ & $1,019(100.0)$ & \\
\hline \multicolumn{5}{|l|}{ Sex } \\
\hline Male & $163(4 \mid .6)$ & $229(58.4)$ & $392(100.0)$ & $\chi^{2}=2.914$ \\
\hline Female & $295(47.0)$ & $332(53.0)$ & $627(100.0)$ & $d f=I$ \\
\hline Total & $458(44.9)$ & $561(55.1)$ & $1,019(100.0)$ & $P=0.088$ \\
\hline \multicolumn{5}{|l|}{ Marital status } \\
\hline Never married/single & $53(52.0)$ & $49(48.0)$ & $102(100.0)$ & $\chi^{2}=2.277$ \\
\hline Currently married & $376(44.2)$ & $474(55.8)$ & $850(100.0)$ & $d f=2$ \\
\hline Previously married & $29(43.3)$ & $38(56.7)$ & $67(100.0)$ & $P=0.320$ \\
\hline Total & $458(44.9)$ & $561(55.1)$ & $1,019(100.0)$ & \\
\hline \multicolumn{5}{|l|}{ Religion } \\
\hline Christianity & $170(51.1)$ & $163(48.9)$ & $333(100.0)$ & $\chi^{2}=7.931$ \\
\hline Islam & $279(41.8)$ & $389(58.2)$ & $668(100.0)$ & $d f=2$ \\
\hline Traditional & $9(50.0)$ & $9(50.0)$ & $18(100.0)$ & $P=0.019$ \\
\hline Total & $458(44.9)$ & $561(55.1)$ & $1,019(100.0)$ & Cramér's $V=0.088$ \\
\hline \multicolumn{5}{|l|}{ Educational status } \\
\hline No formal education & $84(42.0)$ & $116(58.0)$ & $200(100.0)$ & $\chi^{2}=4.619$ \\
\hline Primary education & $|4|(43.3)$ & $185(56.7)$ & $326(100.0)$ & $d f=4$ \\
\hline Secondary & $164(45.3)$ & $198(54.7)$ & $362(100.0)$ & $P=0.329$ \\
\hline Postsecondary & $37(55.2)$ & $30(44.8)$ & $67(100.0)$ & \\
\hline Tertiary & $32(50.0)$ & $32(50.0)$ & $64(100.0)$ & \\
\hline Total & $458(44.9)$ & $56 I(55.1)$ & $1,019(100.0)$ & \\
\hline \multicolumn{5}{|l|}{ Occupational status } \\
\hline Unemployed & $43(39.1)$ & $67(60.9)$ & $110(100.0)$ & $\chi^{2}=4.631$ \\
\hline Unskilled labor & $254(43.6)$ & $329(56.4)$ & $583(100.0)$ & $d f=3$ \\
\hline Skilled labor & I 32 (49.1) & 137 (50.9) & $269(100.0)$ & $P=0.201$ \\
\hline Professional & $29(50.9)$ & $28(49.1)$ & $57(100.0)$ & \\
\hline Total & $458(44.9)$ & $561(55.1)$ & $1,019(100.0)$ & \\
\hline \multicolumn{5}{|l|}{ Average monthly income } \\
\hline$<\# \mid, 500$ & $66(40.5)$ & $97(59.5)$ & $163(100.0)$ & $\chi^{2}=3.031$ \\
\hline$\# 1,600-\# 2,500$ & 81 (48.2) & $87(51.8)$ & $168(100.0)$ & $d f=4$ \\
\hline$\# 2,600-\# 5,000$ & $137(43.4)$ & $179(56.6)$ & $316(100.0)$ & $P=0.553$ \\
\hline$\# 5,100-10,000$ & $103(47.7)$ & $113(52.3)$ & $216(100.0)$ & \\
\hline$>\$ 10,000$ & 71 (45.5) & $85(54.5)$ & $156(100.0)$ & \\
\hline Total & $458(44.9)$ & $561(55.1)$ & $1,019(100.0)$ & \\
\hline \multicolumn{5}{|l|}{ House ownership } \\
\hline Rented & $234(45.1)$ & $285(54.9)$ & $519(100.0)$ & $\chi^{2}=0.008$ \\
\hline Owned & $224(44.8)$ & $276(55.2)$ & $500(100.0)$ & $d f=I$ \\
\hline Total & $458(44.9)$ & $561(55.1)$ & $1,019(100.0)$ & $P=0.927$ \\
\hline \multicolumn{5}{|l|}{ Ethnicity } \\
\hline Yoruba & $44 \mid(44.5)$ & $55 \mid(55.5)$ & $992(100.0)$ & $\chi^{2}=3.638$ \\
\hline Others & $17(63.0)$ & $10(37.0)$ & $27(100.0)$ & $d f=I$ \\
\hline Total & $458(44.9)$ & $561(55.1)$ & $1,019(100.0)$ & $P=0.056$ \\
\hline
\end{tabular}

and personal hygiene, while major emphasis was laid on the removal of supernatural influences. The fact that a fifth suggested personal hygiene in this study agreed with another study. ${ }^{16}$ However, in a similar study, adaptation measures suggested by most respondents include efficient water-use practice, adoption of new farming technology, and changes in crops, pasture and grazing systems. In another study, measures identified by most respondents included reducing greenhouse gas emissions, planting of trees, improving farm energy efficiency, and changing soil-management 
practices. ${ }^{15}$ In yet another study, measures included planting of trees, irrigation, and conservation agriculture. ${ }^{13}$ The less scientific solutions recommended by our respondents when compared to other studies could be due to poor knowledge of measures, traditional believes due to their rural inclination, and their low educational status. Adoption of new farming technology through changes to crops, pasture, and grazing systems, eg, would reduce the problem of changing diversity and prevent living things from going into extinction.

The significant but weak association found between educational status and attitude to causes of CC in this study had been reported by other researchers, thus corroborating our finding. ${ }^{12}$ Educational status was not significantly associated with the likelihood of having a positive attitude. In a related study, ${ }^{12}$ association between educational status and hearing about CC showed significant statistical differences according to educational status among respondents. Persons who had completed tertiary education were more likely to have heard about CC compared to other education strata. Education is important in acquiring and interpreting knowledge about $\mathrm{CC}$, and this could explain the inability of respondents in this study to give a highly scientific response to most of the knowledge questions asked in this study compared to other similar studies done elsewhere, most especially outside Nigeria. Though $\chi^{2}$ analysis showed a positive association of attitude with educational, occupational, and marital status, further logistic regression excludes association with educational and marital status. The fact that the majority of respondents were farmers could stimulate their interest and knowledge about $\mathrm{CC}$, and subsequently their showing a positive attitude to $\mathrm{CC}$. Since $\mathrm{CC}$ can have deleterious effects on farmland, crop yield, and soil fertility, as reported in this study, this could have stimulated their interest into getting more aware about CC and ways of reducing its effects in such a way that it would have minimal or no effect on agriculture.

\section{Conclusion}

Nigeria, like many other countries of the world, is vulnerable to the adverse effects of CC. Poor knowledge of causes of CC but good knowledge of effects of CC was found in this study. In addition, about two-thirds of respondents had positive attitudes to causes of $\mathrm{CC}$, while half had positive attitudes to effects of CC. However, the issue of practical use of such knowledge of effects may not have been put into practice. This calls for dissemination of information on CC in sustained health-promotion programs. In addition, these public health interventions should be directed at individuals, families, subpopulations in the community, the community as a whole, and systems within the community. The systematic collection of such information, as in this study, will allow scientists, researchers, and policy makers to design and implement appropriate adaptation strategies for $\mathrm{CC}$ in countries that are especially vulnerable.

\section{Disclosure}

The authors report no conflicts of interest in this work.

\section{References}

1. Intergovernmental Panel on Climate Change. Summary for policymakers. In: Solomon S, Qin D, Manning M, et al, editors. Climate Change 2007: The Physical Science Basis. Contribution of Working Group I to the Fourth Assessment Report of the IPCC. New York: Cambridge University Press; 2007.

2. McMichael A, Campbell-Lendrum D, Corvalan C, et al. Climate Change and Human Health: Risks and Responses. Geneva: WHO; 2003.

3. Frumkin H, Hess J, Luber G, Malilay J, McGeehin M. Climate change: the public health response. Am J Public Health. 2008;98:435-445.

4. World Health Organization. Protecting Health from Climate Change: A Toolkit for Event Organizers. Geneva: WHO; 2008. Available from: http://www.who.int/world-health-day/toolkit/toolkit_en.pdf. Accessed April 14, 2012.

5. McMichael AJ, Campbell-Lendrum D, Kovats S, et al. Climate change. In: Ezzati M, Lopez AD, Rodgers A, Murray CJ, editors. Comparative Quantification of Health Risks: Global and Regional Burden of Diseases Due to Selected Major Risk Factors. Geneva: WHO; 2004: 1543-1850.

6. Shea KM. Global climate change and children's health. Paediatrics. 2007;120:e1359-e1367.

7. Blashki G, McMichael T, Karoly DJ. Climate change and primary health care. Aust Fam Physician. 2007;36:986-989.

8. Ebi KL, Paulson JA. Climate change and children. Pediatr Clin North Am. 2007;54:213-226.

9. Poortinga W, Pidgeon N. Public Perception of Risk Science and Governance: Main Findings of a British Survey of Five Risk Cases. Norwich: University of East Anglia; 2003.

10. Bickerstaff K, Walker G. Public understandings of air pollution: the 'localization' of environmental risk. Glob Environ Change. 2001;11: $133-145$.

11. Read D, Bostrom A, Morgan MG, Fischhoff B, Smuts T. What do people know about global climate change? Part 2. Survey studies of educated laypeople. Risk Anal. 1994;14:971-982.

12. Planning Institute of Jamaica. Report on Climate Change Knowledge, Attitude and Behavioural Practice Survey. Kingston, Jamaica: Caribbean Institute of Media and Communication Knowledge; 2012.

13. Hara KNG. An assessment of the knowledge, attitudes and practices among communities on climate change. 2012: Available from: http://www.ndr.mw:8080/xmlui/handle/123456789/289. Accessed April 1, 2013.

14. Haque MA, Yamamoto SS, Malik AA, Sauerborn R. Households' perception of climate change and human health risks: a community perspective. Environ Health. 2012;11:1.

15. Water in Drylands Collaborative Research Program. Understanding Farmer Knowledge and Attitudes to Climate Change, Climate Variability, and Greenhouse Gas Emissions. Melbourne: Department of Primary Industries; 2009.

16. Rawlins SC, Chen A, Rawlins JM, Chadee DD, Legall G. A knowledge, attitude and practices study of the issues of climate change/variability impacts and public health in Trinidad and Tobago, and St Kitts and Nevis. West Indian Med J. 2007;56:115-121. 
17. Maibach EW, Chadwick A, McBride D, Chuk M, Ebi KL, Balbus J. Climate change and local public health in the United States: preparedness, programs and perceptions of local public health department directors. PLoS One. 2008;3:2838.

18. Syal SS, Wilson RS, Crawford JM, Lutz J. Climate change and human health - what influences the adoption of adaptation programming in the United States public health system? Mitig Adapt Strateg Glob Change. 2011;16:911-924.
19. Sheffield PE, Landrigan PJ. Global climate change and children's health: threats and strategies for prevention. Environ Health Perspect. 2011;119:291-298.

\section{Publish your work in this journal}

Research and Reports in Tropical Medicine is an international, peerreviewed, open access journal publishing original research, case reports, editorials, reviews and commentaries on all areas of tropical medicine, including: Diseases and medicine in tropical regions; Entomology; Epidemiology; Health economics issues; Infectious disease; Laboratory science and new technology in tropical medicine; Parasitology; Public health medicine/health care policy in tropical regions; and Microbiology. The manuscript management system is completely online and includes a very quick and fair peer-review system. Visit http://www.dovepress. com/testimonials.php to read real quotes from published authors.

Submit your manuscript here: http://www.dovepress.com/research-and-reports-in-tropical-medicine-journal 